\title{
SITE INFLUENCE ON ANATOMICAL STRUCTURE OF BALD CYPRESS
}

\author{
Dušan Jokanović, Dragica Vilotić, Vesna Nikolić Jokanović, Sara Lukić \\ Belgrade University, Faculty of Forestry \\ Belgrade, Republic of Serbia \\ Tatjana Ć́irković-Mitrović \\ INSTITUTE OF Forestry \\ Belgrade, Republic of Serbia \\ (Received February 20I9)
}

\begin{abstract}
The paper deals with length of tracheids of bald cypress at two alluvial sites in Serbia. Scope of the paper was to establish site influence (climate, soil, etc.) on mentioned anatomical feature and to quantify it, as well. Axial tracheid changes have been observed depending on three factors: cambial age, zone inside growth ring and stem height where sampling was performed. The paper established gradually increasing of axial tracheid length with cambial age and that did not depend on zone inside growth ring and stem height. There was also significant influence of the zone inside growth ring to axial tracheid length, while stem height where sampling was performed does not have significant influence. There was found relation between factors that determine site such as physical and chemical soil properties and climate from one and axial tracheid length from another side.
\end{abstract}

KEYWORDS: Bald cypress, tracheid length, Veliko ratno ostrvo, Bačka Palanka, climate, soil.

\section{INTRODUCTION}

Bald cypress (Taxodium distichum (L.) Rich.) wood is valuable, especially in its natural habitat - North America. Some important characteristics of bald cypress such as fast radial and height increment, decorative and technical value confirm its forestry significance. Bald cypress was introduced in Europe in 1640 and at first planted as ornamental species, but later it was also used for forest plantations establishing (Vidaković 1982). In Serbia, bald cypress can be considered as introduced species characterized by relatively fast growth. As for Serbia, there is a group of bald cypress stems in Banja Koviljača park (Tucović and Ocokoljić 2005) and it is also present in some parts of Belgrade (Veliko ratno ostrvo and Bačka Palanka), as well as in Novi Sad, Vršac Vrnjačka banja and Kraljevo. 
There are a lot of papers such as Vilotić and Knežević (1994), Vilotić (1992, 1992a), Vilotic et al. (2015), Jacobsen et al. (2007), Günthardt-Goerg et al. (2013), Luostarinen et al. (2017) etc. that confirmed influence of ecological factors (soil and climate) on wood anatomical structure.

The scope of the paper was to explain how tracheid length changes depending on zone inside growth ring, stem height that was sampled and cambial age. Bearing on mind that tracheids play both mechanical and conductive role by conifers, the goal was to investigate site factors influence on these elements.

\section{MATERIAL AND METHODS}

Material selected for this research originates from two locations - Veliko ratno ostrvo and Bačka Palanka - Republic of Serbia. Veliko ratno ostrvo is protected natural area situated between $1,169 \mathrm{~km}$ and $1,172 \mathrm{~km}$ of the Danube river flow close to Belgrade. On the other side, Bačka Palanka is located in the northern part of Serbia (Vojvodina) and there is the only seed stand of bald cypress in the whole Republic.

\section{Climate}

Based on data obtained from meteorological stations Belgrade and Bački Petrovac, two climate factors were analyzed - an average monthly air temperature and medium monthly rainfall quantity. As for Bačka Palanka, an average monthly air temperature during a year was $11.2^{\circ} \mathrm{C}$, while an average monthly air temperature during vegetation season was $18.0^{\circ} \mathrm{C}$. Overall annual rainfall quantity at this locality was $618 \mathrm{~mm}$, while during vegetation season it was $350 \mathrm{~mm}$, which means that about $57 \%$ from the whole rainfall quantity occurs during vegetation season. At Veliko ratno ostrvo, an average monthly air temperature during a year was $12.2^{\circ} \mathrm{C}$, and during vegetation season it was $18.9^{\circ} \mathrm{C}$. Overall annual rainfall quantity at this locality was $693 \mathrm{~mm}$, while during vegetation season it was $395 \mathrm{~mm}$, which means that about $57 \%$ from the whole rainfall quantity occurs during vegetation season. Based on obtained data related to observed climate factors, we can deduce there are very suitable conditions for growth and development of bald cypress at both localities.

\section{Soil}

Physical and chemical soil features at researched sites were established according to pedological analysis. As for texture composition of soil, more suitable conditions were found at Veliko ratno ostrvo. Texture classes such as sandy loam and loam, recorded at Veliko ratno ostrvo, have much greater useful water capacity than texture classes recorded in Bačka Palanka (sand and loamy sand), so there is much more available water for plants at Veliko ratno ostrvo (Popović 2014, Jokanović 2016). As for chemical structure, there was also present more nutrients at Veliko ratno ostrvo (Jokanović 2016). Ivanišević (1993) and Pekeč (2010) concluded there are significant differences between some texture classes related to optimal hydrological conditions for plants growth.

\section{Samples preparing}

Overall six trees of bald cypress (Taxodium distichum (L.) Rich.) from both localities were harvested. Each test tree was marked on the side facing north because of further investigations on anatomical properties. Disks, approximately $5 \mathrm{~cm}$ thick, were cut at the base $(0.3 \mathrm{~m})$ and on breast height $(1.3 \mathrm{~m})$ from each tree. Radial segments (north-south orientation) were cut from each disc and annual growth rings were marked along one radius. All growth rings from the pith to the bark were included. 
As for laboratory work, mentioned discs were transported into Laboratory for wood anatomy at Faculty of Forestry in Belgrade. Maceration had to be performed in order to measure tracheid length. Maceration was performed according to Franklin's method (Franklin 1945).

Wood tissue maceration of Taxodium distichum (L.) Rich. samples was carried out using Franklin's reagent (mixture of 30\% of hydrogen peroxide and glacial acetic acid in 1:1 proportion) in the Laboratory for wood anatomy, Faculty of Forestry, Belgrade. The prepared reagent was dosed onto chopped wooden samples in glass test tubes, closed with glass plugs, and left in a dryer for 24 hours, exposed to a temperature of $65^{\circ} \mathrm{C}$. The sampled material was transformed into pulp, which was later rinsed with distilled water. Macerated material was stained using safranin, then placed on microscope (Trinocular Microscope model IS.1153-EPL, Euromex, Holland) slides and mounted in glycerin gelatin (Figs. 2 and 4). In order to perform tracheid length measurements, overall four zones were established: (1) close to the core that includes a few initial growth rings, (2) situated in juvenile wood zone, (3) in the central part, and finally (4) close to the bark (Jokanović 2016).

Statistical analysis of results was carried out using Statistica 7. Repeated measures analysis of variance (ANOVA) was used to test significance of differences in radial distribution of selected tracheid characteristics, as well as their variations within and between two bald cypress populations.

\section{RESULTS AND DISCUSSION}

As for Bačka Palanka stems on the base $(0.3 \mathrm{~m})$, an average tracheid length in earlywood was $1.68 \mathrm{~mm}$, while minimal and maximal values were $0.3 \mathrm{~mm}$ and $2.9 \mathrm{~mm}$, respectively. Standard deviation was 0.5184 . As for latewood tracheids at the same locality and on the same height, its average value was $1.69 \mathrm{~mm}$, while extreme values were $0.2 \mathrm{~mm}$ and $2.9 \mathrm{~mm}$, respectively. Standard deviation was 0.6153 . Based on Tab. 1 , it can be established there is no statistically significant difference in tracheid length between earlywood and latewood. Based on Tab. 1, it can be established there is no statistically significant difference between early- and latewood tracheid length.

Tab. 1: Medium tracheid length in early-and latewood (Bačka Palanka).

\begin{tabular}{|c|c|c|}
\hline & \multicolumn{2}{|c|}{ Tukey HSD test } \\
& Homogenous groups, alpha $=0.05000$ \\
\hline & Early-late wood, 0.3 $\mathbf{~ m}$ & Early-late wood, 1.3 m \\
\hline Early wood & $1.685152^{\mathrm{a}}$ & $1.682348^{\mathrm{a}}$ \\
\hline Late wood & $1.694621^{\mathrm{a}}$ & $1.806212^{\mathrm{b}}$ \\
\hline & Error: Between MS $=0.32372$, & $\begin{array}{c}\text { Error: } \text { Between } \mathrm{MS}=0.31646, \\
\mathrm{df}=2638.0\end{array}$ \\
\hline
\end{tabular}

Average values in the same column with different letter $(a, b)$ are statistically different for $\mathrm{p}<0.05$ (Post hoc Tukey's HSD test)

On the Fig. 1a is displayed changing of an average tracheid length at the base depending on cambial age. Earlywood tracheids are the shortest at the beginning, in juvenile zone. As for earlywood tracheids, close to the pith (1-4 growth rings) was established the lowest value of medium tracheid length, $0.99 \mathrm{~mm}$. With cambial age, earlywood tracheids gradually become longer and culmination was reached between $35^{\text {th }}$ and $44^{\text {th }}$ growth ring, $2.11 \mathrm{~mm}$. After that going to the bark an average earlywood tracheid length decreases. 
As for latewood tracheids at the same height $(0.3 \mathrm{~m})$ in the same locality (Bačka Palanka), the same tendency as in the early wood close to the pith was established - there are the shortest tracheids long about $0.80 \mathrm{~mm}$. After that its length gradually increases until 54th growth ring, but maximal medium tracheid value was established between $45^{\text {th }}$ and $54^{\text {th }}$ growth ring, $2.28 \mathrm{~mm}$. Next phase was characterized by reducing of latewood tracheid value.

As for Bačka Palanka on the breast height $(1.3 \mathrm{~m})$, an average earlywood tracheid length was $1.81 \mathrm{~mm}$, while extreme values were $0.5 \mathrm{~mm}$ and $2.9 \mathrm{~mm}$, respectively (Tab. 1). Standard deviation was 0.4804 .

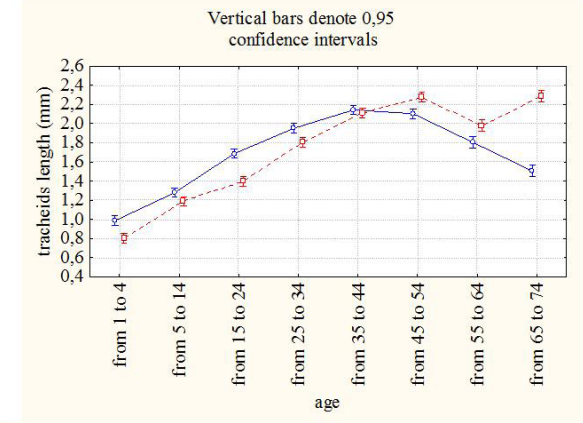

$$
\begin{array}{ll}
\text { BP - on the base, early wood, 1-74 } \\
\text { BP - on the base, late wood, 1-74 }
\end{array}
$$

(a)

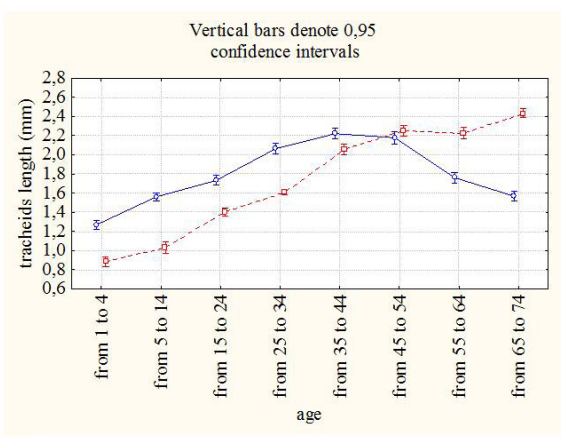

$$
\begin{gathered}
\text { BP - on the brest height, early wood, 1-74 } \\
\text { BP - on the brest height, late wood, 1-74 }
\end{gathered}
$$

(b)

Fig. 1: Changes of an average tracheid length in early-and latewood at the base $(0.3 \mathrm{~m})$ and on the breast height $(1.3 \mathrm{~m})$ depending on cambial age (Backka Palanka).

As for latewood tracheids, an average length was $1.68 \mathrm{~mm}$, while minimum and maximum were $0.3 \mathrm{~mm}$ and $2.9 \mathrm{~mm}$, respectively (Tab. 1). Standard deviation was 0.6341 .

Earlywood tracheids on the breast height $(1.3 \mathrm{~m})$ in Bačka Palanka are the shortest close to the pith $-1.27 \mathrm{~mm}$. After that, they become longer with cambial age and the greatest values were recorded between 35th and 44th growth ring $-2.22 \mathrm{~mm}$. Next phase was characterized by its length reducing with the lowest values in final growth rings $-1.57 \mathrm{~mm}$ (Fig. 1b).

Latewood tracheids are also the shortest close to the pith $(0.88 \mathrm{~mm})$, and after that was established constant rising of tracheid length with maximal values close to the bark $-2.43 \mathrm{~mm}$ (Fig. 1b).

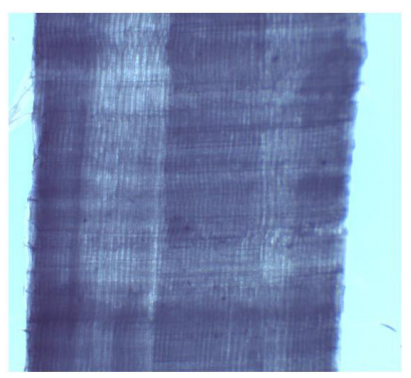

Fig. 2: Strings of macerated early-and latewood tracheids (x 40). 
Vol. 65 (1): 2020

An average early- and latewood tracheid length comparing between each other in Bačka Palanka at the base $(0.3 \mathrm{~m})$ shows existing of statistically significant differences up to 35-44 interval, because between these growth rings earlywood tracheids are much longer than latewood. During 35-44 intervals, there was no significant difference, and after it up to the final growth rings, there was established gradual increasing of latewood tracheid length and decreasing of earlywood tracheid length. There is no statistically significant difference in interval 45-54. Before mentioned interval, earlywood tracheids are much longer, unlike after this interval.

As for Veliko ratno ostrvo, at the base $(0.3 \mathrm{~m})$, an average earlywood tracheid length is $2.49 \mathrm{~mm}$ (Tab. 2). Extreme values are $0.4 \mathrm{~mm}$ and $4.6 \mathrm{~mm}$, respectively, while standard deviation was 1.0608. Medium latewood tracheid length was $1.03 \mathrm{~mm}$ (Tab. 2), minimal $0.3 \mathrm{~mm}$ and maximal $2.3 \mathrm{~mm}$ with standard deviation of 0.4311 .

Tab. 2: Medium tracheid length in early-and latewood (Veliko ratno ostrvo).

\begin{tabular}{|c|c|c|}
\hline \multicolumn{3}{|c|}{ Tukey HSD test } \\
\hline & Eomogenous groups, alpha $=0.05000$ \\
\hline Early wood & $2.490625 \mathrm{a}$ & Early-late wood, 1.3 m \\
\hline Late wood & $1.028125 \mathrm{~b}$ & $2.810625 \mathrm{a}$ \\
\hline & Error: Between MS $=0.85956$, & $0.953750 \mathrm{~b}$ \\
\hline & $\mathrm{df}=958.00$ & $\begin{array}{c}\text { Error: Between MS }=0.59385, \\
\mathrm{df}=958.00\end{array}$ \\
\hline
\end{tabular}

Average values in the same column with different letter $(a, b)$ are statistically different for $\mathrm{p}<0.05$

(Post hoc Tukey's HSD test).

On the base $(0.3 \mathrm{~m})$, with cambial age, an average earlywood tracheid length constantly increases with maximal value in the final growth rings $-4.02 \mathrm{~mm}$ (Fig. 3a).

As for latewood tracheids on the same height and in the same locality (Veliko ratno ostrvo), there are no significant changes of its length close to the pith and in juvenile wood zone. After that comes to its significant increasing to maximal $1.55 \mathrm{~mm}$ and that was followed with reducing of its value to minimum $-0.71 \mathrm{~mm}$ (Fig. 3a). The same tendency was recorded for both early- and latewood tracheid length on the breast height $(1.3 \mathrm{~m})$ on Veliko ratno ostrvo (Fig. 3b).

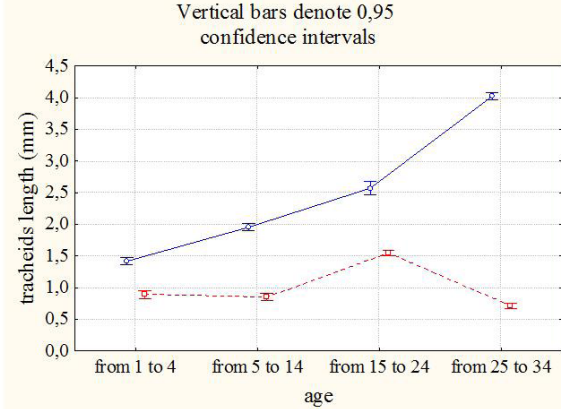

$$
\begin{aligned}
& \text { VRO - on the base, early wood, 1-34 } \\
& \text { VRO - on the base, late wood, 1-34 }
\end{aligned}
$$

(a)

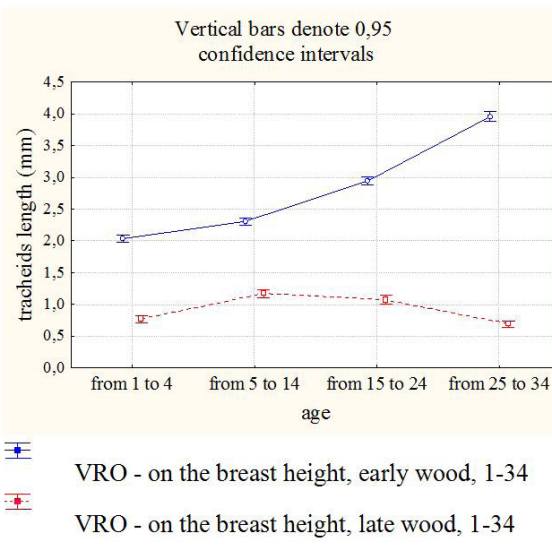

(b)

Fig. 3: Changes of an average tracheid length in early-and latewood at the base $(0.3 \mathrm{~m})$ and on the breast height $(1.3 \mathrm{~m})$ depending on cambial age (Veliko ratno ostrvo). 


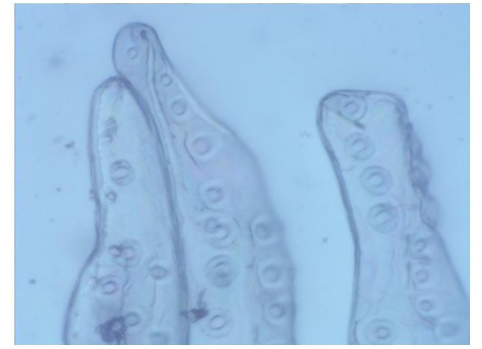

Fig. 4: Macerated tracheids (x 400).

Based on obtained results, significant difference was established, not only in values, but also in growth tendencies of tracheid length with cambial age depending on locality.

In Bačka Palanka, earlywood tracheids are the shortest in juvenile zone, then become longer with culmination between $35^{\text {th }}$ and $44^{\text {th }}$ growth ring, and then its length decreases going to the bark. As for latewood tracheids, they are also the shortest close to the pith, and then become longer with maximal value close to the bark. The same tendencies were recorded both at the base and on the breast height in Bačka Palanka.

As for Veliko ratno ostrvo, unlike earlywood tracheids with remarkable length increasing from the pith to the bark, there is decreasing of latewood tracheid length apart from interval 15-24 when culmination was reached. On the breast height was also recorded that earlywood tracheids are much longer than these situated in latewood. Like on the base, on another height $(1.3 \mathrm{~m})$ was recorded the same tendency -by latewood tracheids, apart from interval 5-14, reducing of tracheids length was obvious with minimum reached in the final growth rings.

Comparative analysis of an average tracheid length in radial direction at breast height from both localities has been shown on the Fig. 5. As for the value of this element, it gradually rises from the pith to the bark going to the mutual age of 34 .

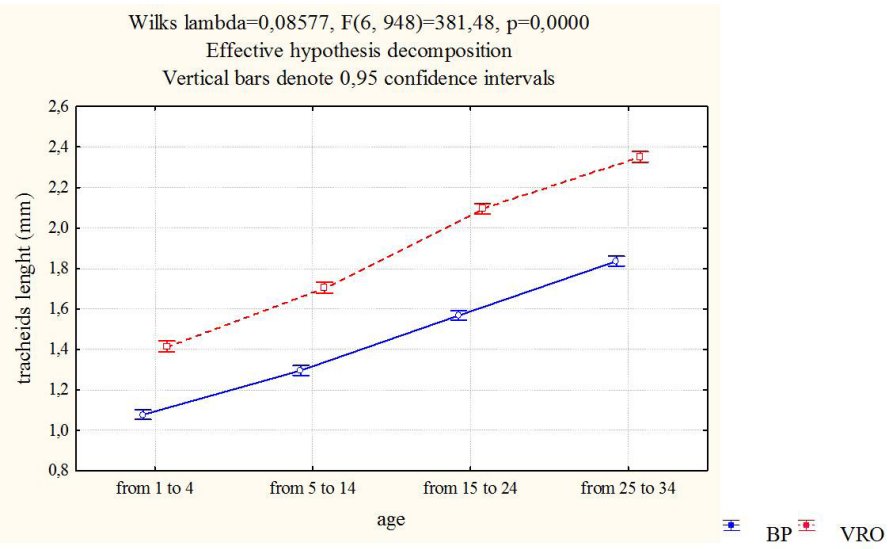

Fig. 5: Distribution of an average tracheid length in radial direction at both localities.

The influence of different sites and tracheid distance from the pith to the bark to its length has been shown in the Tab. 3 . 
Vol. 65 (1): 2020

Tab. 3: Results of variance analysis of tracheid length properties from two localities in radial direction, from the pith to the bark.

\begin{tabular}{|c|c|c|c|c|c|}
\hline \multicolumn{6}{|c|}{$\begin{array}{l}\text { Univariate tests of significance for tracheid length } \\
\text { Sigma-restricted parameterization } \\
\text { Effective hypothesis decomposition }\end{array}$} \\
\hline Effect & $\begin{array}{c}\text { Sum of } \\
\text { Squares }\end{array}$ & $\begin{array}{l}\text { Degree of } \\
\text { freedom }\end{array}$ & Mean Square & F-Ratio & P-Value \\
\hline Site & 24.0457 & 1 & 24.0457 & 1224.08 & 0.0000 \\
\hline Age (annual rings 1-34) & 49.7512 & 3 & 16.5837 & 844.22 & 0.0000 \\
\hline $\begin{array}{l}\text { Site * age (annual rings } \\
\text { 1-34) }\end{array}$ & 0.732752 & 3 & 0.244251 & 12.43 & 0.0000 \\
\hline Error & 9.27187 & 472 & 0.0196438 & & \\
\hline
\end{tabular}

*All F-ratios are based on the residual mean square error.

The values of $\mathrm{p}$-test show statistical significance each of factors. Because obtained values are less than 0.05 , both factors have a statistically significant influence on tracheid length at the significance level of $95 \%$. According to soil type and impact of climate characteristics, Veliko ratno ostrvo should be considered as more suitable for bald cypress growth and development than Bačka Palanka. Vasiljević and Hafić (1959) observed relation between tracheid width and length by fir. They concluded that this relation is changeable going from one to another tracheid. As for mentioned relation, they also found there is no significant difference between early and late wood zone. By fast-growing species, tracheids are longer in the first a few growth rings, and then they gradually become shorter (Stairs et al. 1966). This is not compatible with obtained results for bald cypress.

Some research (Seth 1981, Shiokura and Sudo 1984) established that tracheids are very short close to the core, and after that they become much longer, from the juvenile zone up to the bark. This is compatible with obtained results for tracheid length by bald cypress on both locations. By Serbian spruce (Matijević 1988), tracheids are a little bit longer - in the early wood about $4.36 \mathrm{~mm}$, and in the late wood on average $4.70 \mathrm{~mm}$. The longest tracheids are within Sequoia genus - even $10 \mathrm{~mm}$ (Vilotić 2000).

Sirvio and Karenlampi (2001) followed relation between maturation and growth rate from one side and spruce tracheids features from another side. They concluded that tracheid length rises from the pith to the bark, then that aging process contributes to tracheid localization in some part of the meristem, and finally that tracheid shape depends the most on growth rate. By bald cypress, tracheid length increases with ages, and their shape depends a lot on growth rate - in narrower growth rings, tracheids have irregular shape, while in wider growth rings, they are much more regular.

Frimpong-Mensah (1987) found that tracheids are longer by species with a low growth rate compared to these with a high growth rate, even though there are some different results.

Axial tracheids distribution by bald cypress is usually in radial strings, that is similar to tracheids distribution by fir from Veliki Jastrebac mountain (Vilotić 1992a).

Lim and Soh (1997) established by pines that tracheids reduction occurs as a result of, not only decreased length of initial cells, but also because of decreased rate of stem growth.

Measured tracheid length by spruce (Bergqvist et al. 1997), showed that length of undamaged tracheids varies between 2.77 and $3.00 \mathrm{~mm}$. In this research by bald cypress, an average tracheid length goes up to $4 \mathrm{~mm}$, while minimal values are much lower compared to spruce. 
Research conducted on five Canadian woody species (Fujiwara and Yang, 2000), that was related to correlation between tracheid length and growth rings width, established that wider growth rings caused longer axial tracheids. Variation of tracheid dimensions can indicate short term intensity variation of some ecological factors (Vysotskaya and Vaganov1989), while water availability plays a very important role in tracheid length increasing (Abe and Nakai 1999). This coincides with results obtained for bald cypress - much longer tracheids of early wood are present in Veliko ratno ostrvo, whose soil texture is very suitable for useful water capacity increasing (Jokanović 2016).

There was established that latewood tracheids by bald cypress are a bit longer in Bačka Palanka, that can be related to narrower growth rings that affect greater latewood proportion. Ištok et al. (2017) established increasing of wood fibres length by white poplar going from the pith to the bark. All mentioned results completely coincide with tracheid length behaviour depending on cambial age by bald cypress. Jokanović et al. (2017) concluded that latewood proportion is related to site conditions less suitable for bald cypress growth that finally affects narrower growth rings forming. It was also found that radial increment depends a lot on physical and chemical soil features and on quantity of available water (Jokanović et al. 2018).

\section{CONCLUSIONS}

Based on obtained results for tracheid length by bald cypress on two alluvial sites in Serbia, we can deduce that medium tracheid length is greater by early- than by latewood tracheids.

It should be emphasized the difference was not so obvious in Bačka Palanka. In Bačka Palanka, at $0.3 \mathrm{~m}$ an average values of tracheid leng th were the same $(1.69 \mathrm{~mm})$, while at $1.3 \mathrm{~m}$ latewood tracheids were a bit longer $(1.80 \mathrm{~mm})$, than in earlywood $(1.68 \mathrm{~mm})$. As for Veliko ratno ostrvo earlywood tracheids were much longer at both heights $(2.49 \mathrm{~mm}$ at $0.3 \mathrm{~m}$ and $2.81 \mathrm{~mm}$ at $1.3 \mathrm{~m}$ ), than latewood tracheids $(1.02 \mathrm{~mm}$ at $0.3 \mathrm{~m}$ and $0.95 \mathrm{~mm}$ at $1.3 \mathrm{~m}$ ).

An average tracheid length in early wood was characterized by gradual increasing with stem height at both localities. As for Veliko ratno ostrvo, at both heights, there was established gradual increasing of earlywood tracheid length going from the pith to the bark. The same relation was also found in latewood zone apart from a few final growth rings with reducing of tracheid length not depending on stem height. In Bačka Palanka, in earlywood at both heights, tracheids gradually become longer with cambial age with a weak reducing of these values in the final growth rings.

As for latewood zone in the same locality, the longest tracheids are situated in the final growth rings. Tracheid length depends the most on zone where sampling was performed - in earlywood tracheids are much longer in Veliko ratno ostrvo, unlike Bačka Palanka with a small advantage of latewood tracheids. Site conditions are much more suitable in Veliko ratno ostrvo that finally affects faster radial increment and forming of longer tracheids.

Based on all above mentioned, we can conclude that much more attention has to be paid to bald cypress in Serbia because of its, not only decorative, but also forestry importance. Bearing on mind its tracheid length that is greater than by many autochtonous conifers, bald cypress should be much more used for wood utilization purposes. 


\section{REFERENCES}

1. Abe, H., Nakai, T., 1999: Effect of the water status within a tree on tracheidmorphogenesis in Cryptomeria japonica. Trees 14: 124-129.

2. Bergqvist, G., Bergsten, U., Ahlqvist, B., 1997: Effects of radial increment core diameter on tracheid length measurement in Norway spruce. Wood Science and Technology 31(4): 241-250.

3. Franklin, G. L., 1945: Preparation of thin-wood sections of synthetic resins and wood-resin composites, and a new macerating method for wood. Nature 155: 51.

4. Frimpong-Mensah, K., 1987. Fibre length and basic density variation in the wood of Norway spruce (Picea abies L Karst) from northern Norway. Communications of the Norwegian Forest Research Institute 40 (1): 1-25.

5. Fujiwara, S., Yang, K.C., 2000: The relationship between cell length and ring width and circumferential growth rate in five Canadian species. IAWA Journal 21(3): 335-345.

6. Günthardt-Goerg, M. S., Kuster, T. M., Arend, M., Vollenweider, P., 2013: Foliage response of young central European oaks to air warming, drought and soil type. Plant Biology 15: 185-197.

7. Ištok, I., Šefc, B., Hasan, M., Popović, G., Sedlar, T., 2017: Fiber characteristics of white poplar (Populus alba L.) juvenile wood along the Drava river. Drvna Industrija 68(3): 241-247.

8. Ivanišević, P., 1993: Uticaj svojstava zemljišta na rast ožiljenica: Populus euramericana Guinier (Dode) cl. I-214 i Populus deltoides Bartr. cl. I 69/55. Doktorska disertacija Šumarski fakultet, Univerzitet u Beogradu, (In English: Influence of soil properties on growth of cuttings: Populus euramericana Guinier (Dode) cl. I-214 and Populus deltoides Bartr. cl. I 69/55), Pp 1-206.

9. Jacobsen A.L., Agenbag L., Esler K.J., Pratt R.B., Ewers F.W., Davis S.D., 2007: Xylem density, biomechanics and anatomical traits correlate with water stress in 17 evergreen shrub species of the Mediterranean-type climate region of South Africa. Journal of Ecology 95: 171-183.

10. Jokanović, D. 2016: Anatomical characteristics of Taxodium distichum (L.) Rich. on alluvial sites in Serbia. Doctoral dissertation, Faculty of Forestry - Belgrade University, Pp 1-203.

11. Jokanović, D., Vilotić, D., Nikolić, V., Nonić, M., Devetaković, J., Stanković, D., 2017: Latewood proportion inside growth rings by bald cypress stems in Serbia. Fresenius Environmental Bulletin. 26 (12 A): 7925-7930.

12. Jokanović, D., Vilotić, D., Nikolić, V., Šijačić-Nikolić, M., Lakušić, B., Jović, Đ., 2018: Growth rings width of bald cypress stems from two alluvial sites in Serbia. Fresenius Environmental Bulletin 27 (1): 306-312.

13. Lim, D.O. and Soh, W.Y., 1997: Cambial development and tracheid length of dwarf pines (Pinus densiflora and P.thunbergii). IAWA Journal 18 (3): 301-310.

14. Luostarinen,K., Hakkarainen, K., Kaksonen, H., 2017: Connection of growth and wood density with wood anatomy in downy birch grown in two different soil types, Scandinavian Journal of Forest Research 32 (8): 789-797.

15. Matijević, B., 1988: Anatomska građa drveta Picea omorika (Pančić) Purkyne sa lokaliteta Crvene stene - Tara. In: Monography „Flora of the National Park Tara“. Bajina Bašta, (In English: Anatomy structure of Picea omorika (Pančić) Purkyne timber from Crvene stene locality - Tara), pp. 557-561. 
16. Pekeč, S., 2010: Pedološke i hidrografske karakteristike zaštićenog dela aluvijalne ravni aluvijuma u Srednjem Podunavlju. Doktorska disertacija, Poljoprivredni fakultet, Univerzitet u Novom Sadu, Novi Sad, (In English: Pedological and hydrographic characteristics of the protected part of the alluvial site of alluvium in the Central Danube region), Pp 1-212.

17. Popović, V., 2014: Procena genetskog potencijala taksodijuma (Taxodium distichum (L.) Rich.) u semenskoj sastojini kod Bačke Palanke. Doktorska disertacija, Faculty of Forestry - Belgrade University, (In English: Assessment of bald cypress (Taxodium distichum (L.) Rich.) genetic potential in seed stand near Backa Palanka), Pp 1-205.

18. Seth, M. K., 1981: Variation in tracheid length in blue pine (Pinus wallichiana A.B. Jackson). Part 2: Radial pattern of variation in tracheid length in the first-formed earlywood from pith to bark. Wood Science and Technology 15: 275-286.

19. Shiokura, T., Sudo, S., 1984: The classification of juvenile wood and its perimeter in coniferous trees. Proceedings, Pacific Regional Wood Anatomy Conference, October 1-7, Tsukuba, Ibaraki, Japan, Pp 76-78.

20. Sirvio, J., Karenlampi, P., 2001: The effects of maturity and growth rate on the properties of spruce wood tracheids. Wood Science and Technology 35 (6): 541-554.

21. Stairs, G.R., Marton, R., Brown, A.F., Rizzio, M., Petrik, A., 1966: Anatomical and pulping properties of fast-and-slow-grown Norway spruce. Tappi Journal 49 (7): 296-300.

22. Tucović, A., Ocokoljić, M., 2005: Taxodium ascendens Brongn. - alohtona vrsta četinara u Srbiji. (In English: Taxodium ascendens Brongn. - Allochthonous conifer species in Serbia). Glasnik Šumarskog fakulteta 92: 159-166.

23. Vasiljević, S., Hafić, V., 1959: Istraživanje radijalne širine traheida kod Picea excelsa L. i Abies pectinata DC. Glasnik Šumarskog fakulteta, (In English: Examination of radial width of tracheids in Picea excelsa L. and Abies pectinata DC.), Pp 363-379.

24. Vidaković, M., 1982: Četinjače, Familija Taxodiaceae, JAZU, Zagreb, pp. 604-608.

25. Vilotić, D., 1992: Anatomical structure of trees Virginia Live Oak (Quercus virgiliana Ten./Ten.) at different sites of the Deliblato sand. $\mathrm{PhD}$, University of Belgrade, Faculty of Forestry, Belgrade, Serbia, Pp 1-117.

26. Vilotić, D., 1992a: Anatomska građa debla jele (Abies alba Mill.), In: Monografija „Flora severnog dela Velikog Jastrepca“. Kruševac, (In English: Anatomical structure of fir trunks (Abies alba Mill.) In: Monography “Flora of northern part of Veliki Jastrebac”), Pp 350-351.

27. Vilotić, D., 2000: Uporedna anatomija drveta, Šumarski fakultet - Univerzitet u Beogradu, (In English: Comparative wood anatomy), Pp 1-176.

28. Vilotić, D., Knežević, M., 1994: Study of Virginia Live Oak (Quercus virgiliana /Ten./ Ten.) width of vessel elements at different sites of the Deliblato sand. The Deliblato sands - Proceedings VI (2): 299-306, Belgrade.

29. Vilotić, D., Popović, J., Mitrović, S., Šijačić-Nikolić, M., Ocokoljić, M., Novović, J., Veselinović, M., 2015: Dimensions of mechanical fibres in Paulownia elongata S.Y. Hu Wood from different habitats. Drvna Industrija 66 (3): 229-234.

30. Vysotskaya, L.G., Vaganov, E.A., 1989: Components of the variability of radial cell size in tree rings of conifers, IAWA Bulletin10 (4): 417-426. 
Dušan Jokanović*, Dragica Vilotić, Vesna Nikolić Jokanović, Sara Lukić

Belgrade University

FACUlty OF Forestry

Kneza Višeslava I

IIOZO BELGRADE

Republic of Serbia

*Corresponding author: dusan.jokanovic@sfb.bg.ac.rs

\author{
Tatjana Ćirković-Mitrović \\ InSTITUTE OF Forestry \\ Kneza Višeslava 3 \\ IIOZO BELGRADE \\ Republic of Serbia
}


